\title{
5-HT receptors on interstitial cells of Cajal, smooth muscle and enteric nerves
}

\author{
M. M. WOUTERS $,{ }^{\star}, \dagger, \ddagger$ G. FARRUGIA ${ }^{\star}, \dagger, \ddagger \&$ M. SCHEMANN $\S$ \\ ^Enteric Neuroscience Program, Mayo Clinic College of Medicine, Rochester, MN, USA \\ $\dagger$ Division of Gastroenterology and Hepatology, Mayo Clinic College of Medicine, Rochester, MN, USA \\ $\ddagger$ Department of Physiology and Biomedical Engineering, Mayo Clinic College of Medicine, Rochester, MN, USA \\ $\S$ Human Biology, TU Munich, Freising-Weihenstephan, Germany
}

\begin{abstract}
The majority of the body's serotonin (5-HT) is produced by the gastrointestinal tract. 5-HT has several functions in the gastrointestinal tract. 5-HT is a paracrine signalling molecule released from enterochromaffin cells, a survival and proliferating factor and a neurotransmitter. The actions of 5-HT are transduced by a large family of 5-HT receptors, several of which are expressed on different gastrointestinal cell types including enteric nerves, smooth muscle and interstitial cells of Cajal (ICC). This review will summarize recent advances in understanding the role of 5-HT in regulating function of ICC, and the expression and function of 5-HT receptors on muscle and enteric nerves in human tissue. Rodent ICC express several 5- $\mathrm{HT}$ receptors including 5- $\mathrm{HT}_{2 B}$ receptors which regulate ICC survival and proliferation. Human smooth muscle and enteric neurons also express several 5-HT receptor subtypes. Expression and function of these receptors is significantly different from small laboratory animals. 5- $\mathrm{HT}_{7}$ receptor activation causes relaxation of muscle, whereas 5- $\mathrm{HT}_{2 B}$ receptors increase muscle activity. The $5-\mathrm{HT}_{4}$ receptor appears to mediate both inhibition and activation of smooth muscle involving myogenic as well as neural actions. Despite the abundant expression of 5-HT $\mathrm{T}_{3}$ receptors in the human enteric nervous system no functional correlate has been as yet demonstrated.
\end{abstract}

Keywords 5-HT receptor, human enteric nervous system, human smooth muscle, serotonin.

Address for correspondence

Gianrico Farrugia MD, Division of Gastroenterology and Hepatology, Mayo Clinic, 200 First Street SW, Rochester, MN 55905, USA.

Tel: +1 507284 4695; fax: +1 507284 0266;

e-mail: farrugia.gianrico@mayo.edu

Received: 28 December 2006

Accepted for publication: 17 January 2007

\section{SEROTONIN AND INTERSTITIAL CELLS OF CAJAL}

The majority of the body's serotonin (5-HT) is produced by the gastrointestinal tract. ${ }^{1}$ Ninety per cent of 5 -HT is produced by enterochromaffin cells (EC), found in the gastrointestinal epithelium. ${ }^{2}$ The other major source of 5-HT in the gastrointestinal tract are enteric neurons, in particular interneurons. ${ }^{3,4}$ In some species, mast cells contain high levels of 5- $\mathrm{HT}^{5-7}$ and platelets avidly take up and deliver 5-HT. ${ }^{8,9}$ The actions of 5-HT are transduced by a large family of 5 -HT receptors divided in seven classes $\left(5-\mathrm{HT}_{1}-5-\mathrm{HT}_{7}\right) .5-\mathrm{HT}$ has several distinct functions in the gastrointestinal tract. 5-HT acts as a paracrine factor transducing information from EC to intrinsic primary afferent neurons ${ }^{1}$ and to adjacent cells in the mucosa and submucosa. ${ }^{10}$ Furthermore, 5 -HT is a neurotransmitter ${ }^{11}$ and is also increasingly recognized as a survival factor. ${ }^{12,13}$ Control of gastrointestinal motility requires the coordinated activity of several cell types including nerves, smooth muscle cells and interstitial cells of Cajal (ICC). ICC are now known to be essential for normal motility. ${ }^{14}$ Several receptors are expressed on ICC $^{15}$ including 5-HT receptors. ${ }^{16-18}$

An understanding of the potential role that 5-HT receptors expressed on ICC may play in the control of ICC function and survival requires an understanding of the different roles that ICC play in the control of gastrointestinal motility. ICC are a specialized mesenchymal cell type in the gastrointestinal tract that are neither neurons nor smooth muscle cells. The best studied function of ICC is the generation of spontaneous, rhythmic electrical oscillations called slow waves (the pacemaker function of ICC). ${ }^{19}$ In stomach and small intestine, ICC surrounding the neuronal myenteric plexus (ICC-MP) and in conjunction with intramuscular ICC (ICC-IM) generate and propagate 
slow waves. ${ }^{20,21}$ In the colon, slow waves appear to originate from ICC at the level of the submucosa (ICCSMP). ${ }^{22}$ Also, in colon, ICC-MP may drive the cyclic depolarizations responsible for high-amplitude contractions. ${ }^{23}$ Slow waves are conducted passively to neighbouring smooth muscle where they produce rhythmical membrane potential changes. ${ }^{24,25}$ As contractions only occur during the depolarization phase of the slow wave, slow waves determine the maximal frequency of gastrointestinal musculature contractions. Subclasses of ICC such as ICC-IM and ICC at the level of the deep muscular plexus (ICC-DMP) are in close contact with varicose endings of enteric motor neurons. ${ }^{26}$ These ICC are involved in the conduction and amplification of neuronal signals from excitatory cholinergic and inhibitory nitrergic motor neurons. ${ }^{27,28}$ Together with the dual roles of ICC in pacing the gastrointestinal tract and amplifying neurotransmission, ICC also release carbon monoxide $(\mathrm{CO})^{29-31}$, a critical hyperpolarizing factor required for the maintenance of intestinal smooth muscle membrane potential and its gradient. ${ }^{32}$ Finally, ICC act as mechanosensors through mechanosensitive ion channels expressed on the ICC cell membrane. ${ }^{33,34}$

\section{THE EXPRESSION AND ROLE OF SEROTONIN RECEPTORS ON RODENT ICC}

Of the seven classes of 5-HT receptors known, $5-\mathrm{HT}_{1}$, $5-\mathrm{HT}_{2}, 5-\mathrm{HT}_{3}, 5-\mathrm{HT}_{4}$ and $5-\mathrm{HT}_{7}$ receptors are expressed in the gastrointestinal tract and affect gastrointestinal motor function. ${ }^{35}$ So far, of these, only two 5 -HT receptors have been described on rodent ICC; 5- $\mathrm{HT}_{3}$ and $5-\mathrm{HT}_{4}$ with recent evidence for a third, 5$\mathrm{HT}_{2}$. Data regarding the expression and function of 5-HT receptors on human ICC are lacking and therefore this part of the review will focus on the rodent literature.

\section{THE 5-HT 3 RECEPTOR}

$5-\mathrm{HT}_{3}$ receptors are ligand-gated cation channels. ${ }^{36}$ Evidence for expression of $5-\mathrm{HT}_{3}$ receptors in ICC comes from work carried out in the rat small intestine. ${ }^{17}$ In rat intestine, $5-\mathrm{HT}_{3}$ receptors are expressed by different cell types including functionally distinct classes of neurons, ICC and endocrine cells. ${ }^{17} 5-\mathrm{HT}_{3}$ receptors are found in both ICC-MP and ICC-DMP. However not all ICC appeared to express $5-\mathrm{HT}_{3}$ receptors, that is some ICC at both the ICC-MP and ICC-DMP did not appear to express $5-\mathrm{HT}_{3}$ by immunohistochemistry.
The role of the $5-\mathrm{HT}_{3}$ receptor on ICC is currently unknown. $5-\mathrm{HT}_{3}$ receptors are ligand-gated cation channels and allow entry of several cations including $\mathrm{Ca}^{2+}$ in some but not all types of $5-\mathrm{HT}_{3}$ receptors. $5-\mathrm{HT}_{3}$ receptor activation results in neurotransmitter release, including acetylcholine, from presynaptic terminals and neuronal excitation of postsynaptic cells. ${ }^{37}$ Given the known function of $5-\mathrm{HT}_{3}$ receptors it can be hypothesized that activation of $5-\mathrm{HT}_{3}$ receptors on ICC would result in rapid depolarization and therefore alteration or initiation of the slow wave.

\section{THE $5-\mathrm{HT}_{4}$ RECEPTOR}

5- $\mathrm{HT}_{4}$ receptors are $\mathrm{G}$ protein-coupled metabotropic receptors. Evidence for expression of $5-\mathrm{HT}_{4}$ receptors in ICC comes from work carried out in the mouse and guinea pig small intestine. ${ }^{16,18}$ Studies using an antibody to $5-\mathrm{HT}_{4}$ showed that together with the presence of $5-\mathrm{HT}_{4}$ receptors in subsets of enteric neurons and smooth muscle cells, the $5-\mathrm{HT}_{4}$ receptor was also expressed in ICC-MP. The expression of $5-\mathrm{HT}_{4}$ in ICCDMP appeared to be much less robust. ${ }^{16,18}$

Similar to the $5-\mathrm{HT}_{3}$ receptor, the role of $5-\mathrm{HT}_{4}$ receptors in ICC is not known as no functional studies have been carried out. $5-\mathrm{HT}_{4}$ receptor agonists acting presynaptically enhance neurotransmitter release at neuron-neuronal synapses ${ }^{38}$ while $5-\mathrm{HT}_{4}$ receptor agonists acting on smooth muscle cause relaxation. ${ }^{39}$ The $5-\mathrm{HT}_{4}$ receptor is also thought to be coupled by $\mathrm{G}_{\mathrm{s}}$ to the stimulation of adenylyl cyclase, resulting in an increase in cyclic AMP (cAMP) and activation of protein kinase $\mathrm{A} .{ }^{40} \mathrm{cAMP}$ has been shown to mediate slow wave amplitude and frequency in murine ICC suggesting a potential role for the $5-\mathrm{HT}_{4}$ receptor in modulating slow waves. ${ }^{41}$ The $5-\mathrm{HT}_{4}$ receptor also appears to be involved in neuronal development and survival. ${ }^{42}$ Whether activation of the $5-\mathrm{HT}_{4}$ receptor does in fact play a role in the survival of ICC or is involved in the generation and propagation of the electric slow wave by increasing cAMP levels remains to be elucidated.

\section{OTHER 5-HT RECEPTORS EXPRESSED ON ICC}

Recent data suggest that $5-\mathrm{HT}_{2 \mathrm{~B}}$ receptors are expressed in ICC. ICC networks are not fixed in number, rather the ICC networks turnover in health. ICC can disappear under certain circumstances by programmed cell death, necrosis or transdifferentiation, and in more permissive conditions they can reappear through proliferation or differentiation. For example, partial obstruction of the murine ileum by a clip leads to 
disrupted ICC networks oral to the site of obstruction. Removal of the obstruction results in the redevelopment of ICC networks within 30 days. ${ }^{43}$ Trichinella spiralis infection to the mouse small intestine results in disrupted ICC networks 10-15 days after infection with complete ICC recovery by 40 days after infection. ${ }^{44}$ In the human, a patient with hypertrophic pyloric stenosis did not have any ICC in the pylorus at the time of myotomy but a full network of ICC was present 4 months after the first surgery. ${ }^{45}$ The mechanisms underlying ICC disappearance and recovery are unknown.

Evidence, mostly from outside the gastrointestinal tract and also in studies on enteric nervous system (ENS) development, indicates that 5-HT can regulate cell survival and proliferation. ${ }^{12,46}$ Four serotonin receptors have been implicated in transduction of the 5-HT signal to regulate cell survival and proliferation, namely $5-\mathrm{HT}_{1 \mathrm{~A}}, 5-\mathrm{HT}_{1 \mathrm{D}}, 5-\mathrm{HT}_{2 \mathrm{~B}}$ and $5-\mathrm{HT}_{2 \mathrm{C}}$ receptors. ${ }^{12,46-56}$ Immunohistochemistry on human intestine and single cell PCR on mouse derived intestinal cells revealed that $5-\mathrm{HT}_{2 \mathrm{~B}}$ receptors are expressed on neurons, smooth muscle cells and neonatal and adult ICC. ${ }^{57-60}$ Activation of the $5-\mathrm{HT}_{2 \mathrm{~B}}$ receptor in vitro, resulted in increased neonatal ICC numbers through proliferation ${ }^{60}$ suggesting a potential role of the $5-\mathrm{HT}_{2 \mathrm{~B}}$ receptor in regulating ICC numbers.

\section{SOURCE OF 5-HT FOR ICC}

5-HT receptors are abundantly expressed in the gastrointestinal tract. However, the source of 5-HT that can activate the different receptors found is still not clear for all the cell types that express 5-HT receptors, including ICC. 5-HT is found in significant quantities in $\mathrm{EC}^{2}$ serotonergic neurons, ${ }^{4}$ platelets ${ }^{8}$ and mast cells. ${ }^{5}$

In non-diseased tissue, it is unlikely that ICC and myenteric neurons respond to $5-\mathrm{HT}$ released by the EC in the mucosa because the 5-HT transporters present in serotonergic neurons, mucosal and submucosal cells will rapidly take up 5-HT. ${ }^{61,62}$ However, a subset of intrinsic primary afferent neurons located in the submucosal plexus project to the myenteric plexus and are activated by mucosal 5 -HT. ${ }^{63,64}$ These submucosal to myenteric projections may result in mucosal 5-HT activating myenteric neurons and, indirectly, ICC.

In inflammation, 5-HT transporters have been shown to be downregulated ${ }^{65,66}$ and 5 -HT production increased $^{65}$ making it more likely that mucosally generated 5-HT can reach ICC and activates the expressed receptors. Another possible source of 5-HT are serotonergic interneurons. Serotonergic interneu- rons represent about $2 \%$ of the total number of enteric neurons. ${ }^{4}$ However, while in the myenteric plexus they may represent a possible source of 5-HT for other myenteric neurons, interneurons do not make direct contact with ICC and therefore would be unlikely to provide sufficient 5-HT to activate ICC 5-HT receptors. Mast cells can represent a source for 5-HT. Mast cells are known to be in close apposition to $\operatorname{ICC}^{67}$ and therefore may be one of the sources of 5-HT. Murine, but not human, mast cells contain storage proteins that can bind 5-HT in order to release it to the appropriate target cells. ${ }^{5,7}$ Finally, platelets are a rich source of $5-\mathrm{HT}^{8,9}$ and may serve as a significant $5-\mathrm{HT}$ source. It is not currently known if platelet derived 5-HT can activate ICC 5-HT receptors.

\section{5-HT RECEPTORS ON ENTERIC NEURONS AND SMOOTH MUSCLE: HUMAN STUDIES}

5-HT can be released in response to several stimuli like mechanical distortion, mucosal stroking or electrical stimulation of enteric neurons. The crucial role of 5-HT for transmission within enteric circuits and initiation of normal reflex activity in animal models has been expanded by studies which suggested impairment of serotonergic mechanisms as one of the factors in the pathogenesis of gut diseases. Indeed, 5-HT receptor modulating substances are effective in relieving symptoms associated with irritable bowel syndrome (IBS), such as abdominal pain or altered stool frequency and consistency. ${ }^{68}$ The increased number of EC cells in some IBS patients ${ }^{69}$ further implicates a role for 5-HT in IBS pathogenesis.

In this section, we summarize the current knowledge on 5-HT receptor expression in human enteric nerves and smooth muscle (see Fig. 1) by focusing on $5-\mathrm{HT}_{3}, 5-\mathrm{HT}_{4}, 5-\mathrm{HT}_{7}$ and 5- $\mathrm{HT}_{2 \mathrm{~B}}$ receptors.

\section{THE 5- $\mathrm{HT}_{3}$ RECEPTOR}

There are three evolutionary arms of $5-\mathrm{HT}_{3}$ receptors which are $5-\mathrm{HT}_{3 \mathrm{~A}}, 5-\mathrm{HT}_{3 \mathrm{~B}}$ and $5-\mathrm{HT}_{3 \mathrm{C}-\mathrm{E}}$. RT-PCR expression analysis revealed that all know $5-\mathrm{HT}_{3}$ receptor subunits are expressed in the human gut. ${ }^{70,71}$ However, there is a striking region specific expression of the different subunits. ${ }^{70,71} 5-\mathrm{HT}_{3 \mathrm{C}}$ and in particular $5-\mathrm{HT}_{3 \mathrm{C} 1.3}$ is mainly expressed in the small intestine. $5-\mathrm{HT}_{3 \mathrm{D}}$ is only expressed in the colon, kidney and liver, whereas the $5-\mathrm{HT}_{3 \mathrm{E}}$ subunit is exclusively expressed in the small intestine and colon but not in other organs. There is a low expression of $5-\mathrm{HT}_{3 \mathrm{~A}}$ and $5-\mathrm{HT}_{3 \mathrm{~B}}$ subunits and a total lack of $5-\mathrm{HT}_{3 \mathrm{D}}$ and $5-\mathrm{HT}_{3 \mathrm{E}}$ 


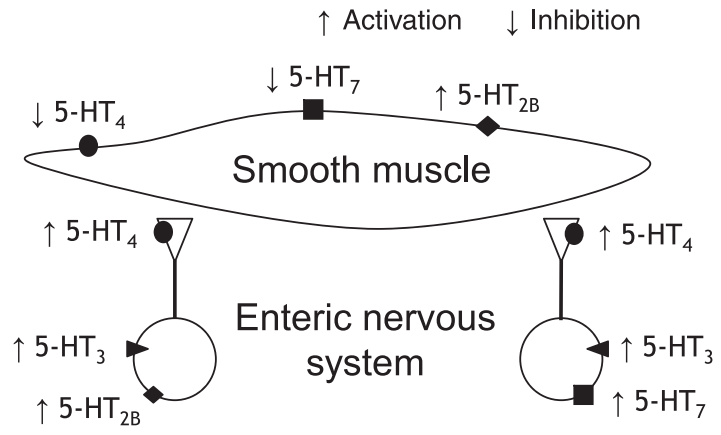

\section{Excitatory pathways}

Inhibitory pathways

Figure 1 Summary of current knowledge on 5-HT receptor localization and their putative functions in the human intestine.

subunits in the human stomach. ${ }^{70}$ The functional relevance of the expression of different $5-\mathrm{HT}_{3}$ subunits in the human gut remains unknown. It has been known that the properties of $5-\mathrm{HT}_{3}$ receptors change with different combinations of the subunits. ${ }^{72}$ Homomeric $5-\mathrm{HT}_{3 \mathrm{~A}}$ receptors reveal low conductance while heteromeric $5-\mathrm{HT}_{3 \mathrm{~A} / \mathrm{B}}$ receptors display large conductance. However, there are only very minor differences in their respective pharmacological profiles. ${ }^{73}$ Co-expression of $5-\mathrm{HT}_{3 \mathrm{~A}}$ with $5-\mathrm{HT}_{3 \mathrm{C}}$ reduces biological function of $5-\mathrm{HT}_{3 \mathrm{~A}}$ receptors as the magnitude of $5-\mathrm{HT}$ induced currents is reduced. ${ }^{74}$ It is intriguing to speculate that, if $5-\mathrm{HT}_{3 \mathrm{C}}$ is involved in serotoninresponsiveness of the gut, $5-\mathrm{HT}_{3 \mathrm{C}}$-specific agents with less activity at $5-\mathrm{HT}_{3 \mathrm{~A}}$ may be more desirable agents for treatment of diseases such as IBS.

5-HT mediates rapid excitatory responses in human submucosal neurons that are mediated by $5-\mathrm{HT}_{3}$ receptors which comprise both $5-\mathrm{HT}_{3 \mathrm{~A}}$ and $5-\mathrm{HT}_{3 \mathrm{~B}}$ receptor subunits. ${ }^{75}$ Only a relatively small component of 5-HT evoked action potential discharge may be mediated by other 5-HT receptors none of which have been electrophysiologically identified today. Although $5-\mathrm{HT}_{3}$ receptors are present in the majority of human submucosal and myenteric neurons ${ }^{75}$, their functional relevance is not clear. For example, the $5-\mathrm{HT}_{3}$ agonist 2-methyl-5-HT does not evoke secretion in human mucosa-submucosa preparations. ${ }^{75}$ Likewise, while $5-\mathrm{HT}_{3}$ receptors are involved in the initiation and/or transmission of muscle and secretory reflex activity in the guinea-pig gut, they do not appear to be crucial for the peristaltic reflex in the human colon. ${ }^{76,77}$ This lack of demonstration for the function of $5-\mathrm{HT}_{3}$ receptors in the isolated human gut together with the clinical observation that $5-\mathrm{HT}_{3}$ antagonists improve symptoms in IBS patients ${ }^{78}$ raises the question of whether this beneficial effect is rather due to actions on non-ENS targets or whether there is a disease associated alteration in the properties of enteric $5-\mathrm{HT}_{3}$ receptors.

\section{THE $5-\mathrm{HT}_{4}$ RECEPTOR}

$5-\mathrm{HT}_{4}$ receptor mRNA is expressed throughout the human gut at 2-12 fold higher levels as in the liver. ${ }^{79}$ The A, B, C, D, G and I isoforms of the $5-\mathrm{HT}_{4}$ receptor are all present in the human intestine. ${ }^{80,81}$ The $5-\mathrm{HT}_{4 \mathrm{D}}$ splice variant appears to be expressed only in the gut and not in other organs. Activation of $5-\mathrm{HT}_{4}$ receptors results in inhibition and activation of muscle activity in the human colon. While the inhibition appears to be a direct effect on the muscle, the motility enhancing effect is due to the activation of neural excitatory cholinergic pathways. ${ }^{82} \mathrm{~A}$ recent study by Cellek et al. showed that the $5-\mathrm{HT}_{4}$ evoked inhibition of muscle activity may not be a purely myogenic response but involves the activation of inhibitory nitrergic pathways in the ENS, too. ${ }^{83}$ Although these functional data would suggest $5-\mathrm{HT}_{4}$ receptor expression in the ENS, $5-\mathrm{HT}_{4}$ receptor immunoreactivity on enteric nerves has not yet demonstrated in human tissue. In analogy to guinea-pig and mouse ENS, presynaptic $5-\mathrm{HT}_{4}$ receptors which facilitate acetylcholine release have also been postulated in human tissue. A preliminary report describes $5-\mathrm{HT}_{4}$-IR on smooth muscle cells, blood vessels and mast cells but neurons appeared to be negative. ${ }^{84}$ Therefore, one has to consider that the pharmacologically identified neural component of $5-\mathrm{HT}_{4}$ mediated muscle activity may be secondary and due to release from mast cell of mediators that are known to activate human enteric neurons. ${ }^{85}$

Application of $5-\mathrm{HT}_{4}$ agonists onto human intestinal mucosa evokes ascending contraction and descending relaxation together with release of the excitatory transmitter substance $\mathrm{P}$ proximal to the stimulation and release of the inhibitory transmitter vasoactive intestinal peptide distal to the stimulation. ${ }^{86}$ This would suggest that activation of $5-\mathrm{HT}_{4}$ receptors at the mucosal level is sufficient to activate the polarized components of the peristaltic reflex. Mucosal stroking also evokes ascending contraction and descending relaxation involving $5-\mathrm{HT}_{4}$ and $5-\mathrm{HT}_{1 \mathrm{P}}$ but not $5-\mathrm{HT}_{3}$ receptors in the human jejunum. ${ }^{76}$ Intriguingly, none of the receptors are involved in stretch evoked muscle responses. $^{76}$

\section{THE $5-\mathrm{HT}_{7}$ RECEPTOR}

A number of $5-\mathrm{HT}_{7}$ splice variants were described in the human gut. ${ }^{87}$ The functional and pharmacological 
properties of human $5-\mathrm{HT}_{7}$ splice variants are virtually indistinguishable. ${ }^{87}$ Functional studies indicate that 5-HT induced muscle relaxation in the human colon is mediated by $5-\mathrm{HT}_{7}$ receptors. ${ }^{88}$ It is not entirely clear whether nerves are involved in this effect. Since the relaxation is not affected by $0.3 \mu \mathrm{mol} \mathrm{L}^{-1}$ tetrodotoxin, it has been concluded that the $5-\mathrm{HT}_{7}$ receptor is very likely localized on the muscle ${ }^{88}$ although presynaptic actions at the neuromuscular junction cannot be totally excluded. An earlier study revealed a neural component as 5-HT-evoked inhibition of spontaneous activity was sensitive to $1.5 \mu \mathrm{mol} \mathrm{L}{ }^{-1}$ tetrodotoxin. ${ }^{89}$

\section{THE 5-HT 2 B RECEPTOR}

5 -HT induced activation of muscle is mediated by $5-\mathrm{HT}_{2 \mathrm{~B}}$ receptors in the human colon. ${ }^{90}$ In the muscularis externa, immunoreactivity is highest in the longitudinal muscle layer and in the myenteric plexus while lower expression is found in the circular muscle layer. $^{90}$

\section{SUMMARY}

Rodent ICC express different classes of 5-HT receptors. The source for the receptor ligand is presently unclear, however the differential distribution of the different receptors suggests an active functional role for the receptors, a role that may be amplified during inflammation. ICC $5-\mathrm{HT}_{3}$ and $5-\mathrm{HT}_{4}$ receptors may be involved in regulation of gastrointestinal motility while ICC $5-\mathrm{HT}_{2 \mathrm{~B}}$ receptors may regulate ICC survival and proliferation.

Smooth muscles as well as enteric neurons in the human gut also express several 5-HT receptor subtypes (Fig. 1). 5- $\mathrm{HT}_{7}$ receptor activation causes relaxation of the muscle, whereas $5-\mathrm{HT}_{2 \mathrm{~B}}$ receptors are involved in increased muscle activity. The $5-\mathrm{HT}_{4}$ receptor appears to mediate both inhibition and activation of the smooth muscle. Despite the abundant expression of $5-\mathrm{HT}_{3}$ receptors in the human ENS no functional correlate has been demonstrated yet. Both the cellular expression as well as the function of 5-HT receptors in the human gut is significantly different from those in small laboratory animals.

\section{ACKNOWLEDGEMENTS}

We thank Kristy Zodrow for secretarial assistance and Birgit Kuch for technical assistance. This work was supported by grants NIH DK 57061 and DK 68055 and by grants from the DFG to M.S.

\section{CONFLICT OF INTEREST STATEMENT}

None declared.

\section{REFERENCES}

1 Gershon MD. Review article: serotonin receptors and transporters - roles in normal and abnormal gastrointestinal motility. Aliment Pharmacol Ther 2004; 20: 3-14.

2 Racke K, Schworer H. Regulation of serotonin release from the intestinal mucosa. Pharmacol Res 1991; 23: 1325.

3 Young HM, Furness JB. Ultrastructural examination of the targets of serotonin-immunoreactive descending interneurons in the guinea pig small intestine. J Comp Neurol 1995; 356: 101-14.

4 Costa M, Brookes SJ, Steele PA, Gibbins I, Burcher E, Kandiah CJ. Neurochemical classification of myenteric neurons in the guinea-pig ileum. Neuroscience 1996; 75: 949-67.

5 Tamir H, Theoharides T, Gershon M, Askenase P. Serotonin storage pools in basophil leukemia and mast cells: characterization of two types of serotonin binding protein and radioautographic analysis of the intracellular distribution of $[3 \mathrm{H}]$ serotonin. I Cell Biol 1982; 93: 63847.

6 Coleman J, Holliday M, Kimber I, Zsebo K, Galli S. Regulation of mouse peritoneal mast cell secretory function by stem cell factor, IL-3 or IL-4. I Immunol 1993; 150: 556-62.

7 Enerback L. Serotonin in human mast cells. Nature 1963; 197: 610-1.

8 van Zwieten PA. Pathophysiological relevance of serotonin. J Cardiovasc Pharmacol 1987; 10 (Suppl. 3): S19-25.

9 Vanhoutte PM, Cohen RA. The elusory role of serotonin in vascular function and disease. Biochem Pharmacol 1983; 32: 3671-4.

10 Zhu JX, Wu XY, Owyang C, Li Y. Intestinal serotonin acts as a paracrine substance to mediate vagal signal transmission evoked by luminal factors in the rat. I Physiol (Lond) 2001; 530: 431-42.

11 Kim D-Y, Camilleri M. Serotonin: a mediator of the brain-gut connection. Am I Gastroenterol 2000; 95: 2698-709.

12 Fiorica-Howells E, Maroteaux L, Gershon MD. Serotonin and the 5-HT(2B) receptor in the development of enteric neurons. I Neurosci 2000; 20: 294-305.

13 Nebigil CG, Etienne N, Messaddeq N, Maroteaux L. Serotonin is a novel survival factor of cardiomyocytes: mitochondria as a target of 5-HT2B receptor signaling. FASEB I 2003; 17: 1373-5.

14 Hirst GDS, Edwards FR. Role of interstitial cells of Cajal in the control of gastric motility. J Pharmacol Sci 2004; 96: $1-10$.

15 Epperson A, Hatton WJ, Callaghan B et al. Molecular markers expressed in cultured and freshly isolated interstitial cells of Cajal. Am J Physiol Cell Physiol 2000; 279: C529-39.

16 Liu M, Geddis MS, Wen Y, Setlik W, Gershon MD. Expression and function of 5-HT4 receptors in the mouse enteric nervous system. Am I Physiol Gastrointest Liver Physiol 2005; 289: G1148-63. 
17 Glatzle J, Sternini C, Robin C et al. Expression of 5-HT3 receptors in the rat gastrointestinal tract. Gastroenterology 2002; 123: 217-26.

18 Poole DP, Xu B, Koh SL et al. Identification of neurons that express 5-hydroxytryptamine4 receptors in intestine. Cell Tissue Res 2006; 325: 413-22.

19 Ward SM, Burns AJ, Torihashi S, Sanders KM. Mutation of the proto-oncogene c-kit blocks development of interstitial cells and electrical rhythmicity in murine intestine. J Physiol 1994; 480: 91-7.

20 Thomsen L, Robinson TL, Lee JCF, Hughes MJG, Andrews DW, Huizinga JD. Interstitial cells of Cajal generate a rhythmic pacemaker current. Nat Med 1998; 4: 848-51.

21 Ward SM, Baker SA, de Faoite A, Sanders KM. Propagation of slow waves requires IP3 receptors and mitochondrial $\mathrm{Ca} 2+$ uptake in canine colonic muscles. I Physiol (Lond) 2003; 549: 207-18.

22 Sanders KM, Stevens R, Burke E, Ward SW. Slow waves actively propagate at submucosal surface of circular layer in canine colon. Am I Physiol 1990; 259: G25-63.

23 Pluja L, Alberti E, Fernandez E, Mikkelsen HB, Thuneberg L, Jimenez M. Evidence supporting presence of two pacemakers in rat colon. Am I Physiol Gastrointest Liver Physiol 2001; 281: G255-66.

24 Daniel EE. Communication between interstitial cells of Cajal and gastrointestinal muscle. Neurogastroenterol Motil 2004; 16: 118-22.

25 Schultz T, Daniel V, Daniel EE. Does ICC pacing require functional gap junctions between ICC and smooth muscle in mouse intestine? Neurogastroenterol Motil 2003; 15: 129-38.

26 Wang XY, Paterson C, Huizinga JD. Cholinergic and nitrergic innervation of ICC-DMP and ICC-IM in the human small intestine. Neurogastroenterol Motil 2003; 15: $531-43$.

27 Iino S, Ward SM, Sanders KM. Interstitial cells of Cajal are functionally innervated by excitatory motor neurones in the murine intestine. I Physiol 2004; 556: 521-30.

28 Ward SM, Morris G, Reese L, Wang XY, Sanders KM. Interstitial cells of Cajal mediate enteric inhibitory neurotransmission in the lower esophageal and pyloric sphincters. Gastroenterology 1998; 115: 314-29.

29 Farrugia G, Szurszewski JH. Heme oxygenase, carbon monoxide, and interstitial cells of Cajal. Microsc Res Tech 1999; 47: 321-4.

30 Miller SM, Farrugia G, Schmalz PF, Ermilov LG, Maines MD, Szurszewski JH. Heme oxygenase 2 is present in interstitial cell networks of the mouse small intestine. Gastroenterology 1998; 114: 239-44.

31 Miller SM, Reed D, Sarr MG, Farrugia G, Szurszewski JH. Haem oxygenase in enteric nervous system of human stomach and jejunum and co-localization with nitric oxide synthase. Neurogastroenterol Motil 2001; 13: 121-31.

32 Szurszewski JH, Farrugia G. Carbon monoxide is an endogenous hyperpolarizing factor in the gastrointestinal tract. Neurogastroenterol Motil 2004; 16: 81-5.

33 Thuneberg L, Peters S. Toward a concept of stretch-coupling in smooth muscle. I. Anatomy of intestinal segmentation and sleeve contractions. Anat Rec 2001; 262: $110-24$.

34 Strege PR, Holm AN, Rich A et al. Cytoskeletal modulation of sodium current in human jejunal circular smooth muscle cells. Am I Physiol Cell Physiol 2003; 284: C60-6.

35 De Ponti F. Pharmacology of serotonin: what a clinician should know. Gut 2004; 53: 1520-35.

36 Peters JA, Malone HM, Lambert JJ. Recent advances in the electrophysiological characterization of 5-HT3 receptors. Trends Pharmacol Sci 1992; 13: 391-7.

37 Peters JA, Kelley SP, Dunlop JI, Kirkness EF, Hales TG, Lambert JJ. The 5-hydroxytryptamine type 3 (5-HT3) receptor reveals a novel determinant of single-channel conductance. Biochem Soc Trans 2004; 32(Pt 3): 547-52.

38 Pan H, Galligan JJ. 5-HT1A and 5-HT4 receptors mediate inhibition and facilitation of fast synaptic transmission in enteric neurons. Am I Physiol 1994; 266: G230-8.

39 Prins NH, Van Haselen JFWR, Lefebvre RA, Briejer MR, Akkermans LMA, Schuurkes JAJ. Pharmacological characterization of 5-HT4 receptors mediating relaxation of canine isolated rectum circular smooth muscle. $\mathrm{Br} I$ Pharmacol 1999; 127: 1431-7.

40 Liu M, Geddis MS, Wen Y, Setlik W, Gershon MD. Expression and function of 5-HT4 receptors in the mouse enteric nervous system. Am I Physiol Gastrointest Liver Physiol 2005; 289: G1148-63.

41 Malysz J, Donnelly G, Huizinga JD. Regulation of slow wave frequency by IP3-sensitive calcium release in the murine small intestine. Am I Physiol Gastrointest Liver Physiol 2001; 280: G439-48.

42 Liu M, Gershon MD. Neuroprotective/trophic effects of 5-HT4 receptor stimulation on enteric neurons of mice (Abstract). Neurogastroenterol Motil 2006; 18: 780.

43 Chang IY, Glasgow NJ, Takayama I, Horiguchi K, Sanders KM, Ward SM. Loss of interstitial cells of Cajal and development of electrical dysfunction in murine small bowel obstruction. J Physiol (Lond) 2001; 536: 555-68.

44 Wang XY, Berezin I, Mikkelsen HB et al. Pathology of interstitial cells of Cajal in relation to inflammation revealed by ultrastructure but not immunohistochemistry. Am I Pathol 2002; 160: 1529-40.

45 Vanderwinden J-M, Liu H, Menu R, Conreur J-L, De Laet $\mathrm{M}-\mathrm{H}$, Vanderhaeghen J-J. The pathology of infantile hypertrophic pyloric stenosis after healing. I Pediatr Surg 1996; 31: 1530-4.

46 Fanburg BL, Lee SL. A new role for an old molecule: serotonin as a mitogen. Am I Physiol 1997; 272: L795806.

47 Banasr M, Hery M, Printemps R, Daszuta A. Serotonininduced increases in adult cell proliferation and neurogenesis are mediated through different and common 5-HT receptor subtypes in the dentate gyrus and the subventricular zone. Neuropsychopharmacology 2004; 29: 45060.

48 Huang G-J, Herbert J. The role of 5-HT1A receptors in the proliferation and survival of progenitor cells in the dentate gyrus of the adult hippocampus and their regulation by corticoids. Neuroscience 2005; 135: 803-13.

49 Radley JJ, Jacobs BL. 5-HT1A receptor antagonist administration decreases cell proliferation in the dentate gyrus. Brain Res 2002; 955: 264-7.

50 Cattaneo MG, Fesce R, Vicentini LM. Mitogenic effect of serotonin in human small cell lung carcinoma cells via both 5-HT1A and 5-HT1D receptors. Eur I Pharmacol 1995; 291: 209-11. 
51 Abdouh M, Albert PR, Drobetsky E, Filep JG, Kouassi E. 5-HT1A-mediated promotion of mitogen-activated T and B cell survival and proliferation is associated with increased translocation of NF-kappaB to the nucleus. Brain Behav Immun 2004; 18: 24-34.

52 Sempere T, Urbina M, Lima L. 5-HT1A and beta-adrenergic receptors regulate proliferation of rat blood lymphocytes. Neuroimmunomodulation 2004; 11: 307-15.

53 Lesurtel M, Graf R, Aleil B et al. Platelet-derived serotonin mediates liver regeneration. Science 2006; 312: 104-7.

54 Nebigil CG, Launay JM, Hickel P, Tournois C, Maroteaux L. 5-hydroxytryptamine $2 \mathrm{~B}$ receptor regulates cell-cycle progression: cross-talk with tyrosine kinase pathways. Proc Natl Acad Sci U S A 2000; 97: 2591-6.

55 De Lucchini S, Ori M, Cremisi F, Nardini M, Nardi I. 5-HT2B-mediated serotonin signaling is required for eye morphogenesis in Xenopus. Mol Cell Neurosci 2005; 29: 299-312.

56 De Lucchini S, Ori $M$, Nardini $M$, Marracci S, Nardi I. Expression of 5-HT2B and 5-HT2C receptor genes is associated with proliferative regions of Xenopus developing brain and eye. Brain Res Mol Brain Res 2003; 115: 196201.

57 Streutker KJ, Colley EC, Hillsley K, Kelly SM, Hicks GA, Stead RH. 5-HT2B receptors (5-HT2B) are expressed on neurons and non-neuronal cells in the human gastrointestinal tract, rat colon and rat DRG (abstract). Gastroenterology 2006; 130: 227.

58 Choi DS, Maroteaux L. Immunohistochemical localisation of the serotonin 5-HT2B receptor in mouse gut, cardiovascular system, and brain. FEBS Lett 1996; 391: 45-51.

59 Fiorica-Howells E, Maroteaux L, Gershon MD. 5-HT2B receptors are expressed by neuronal precursors in the enteric nervous system of fetal mice and promote neuronal differentiation. Ann N Y Acad Sci 1998; 861: 246.

60 Wouters MM, Roeder JL, Strege PR, Gibbons SJ, Farrugia G. Proliferation of the interstitial cells of Cajal is induced by serotonin through 5 -HT2B receptors (abstract). Neurogastroenterol Motil 2006; 18: 759.

61 Wade PR, Chen J, Jaffe B, Kassem IS, Blakely RD, Gershon MD. Localization and function of a 5-HT transporter in crypt epithelia of the gastrointestinal tract. I Neurosci 1996; 16: 2352-64.

62 Chen JX, Pan H, Rothman TP, Wade PR, Gershon MD. Guinea pig 5-HT transporter: cloning, expression, distribution, and function in intestinal sensory reception. Am J Physiol 1998; 275: G433-48.

63 Kirchgessner AL, Gershon MD. Projections of submucosal neurons to the myenteric plexus of the guinea pig intestine: in vitro tracing of microcircuits by retrograde and anterograde transport. J Comp Neurol 1988; 277: 48798.

64 Kirchgessner AL, Tamir H, Gershon MD. Identification and stimulation by serotonin of intrinsic sensory neurons of the submucosal plexus of the guinea pig gut: activityinduced expression of Fos immunoreactivity. I Neurosci 1992; 12: 235-48.

65 O'Hara JR, Ho W, Linden DR, Mawe GM, Sharkey KA. Enteroendocrine cells and 5-HT availability are altered in mucosa of guinea pigs with TNBS ileitis. Am I Physiol Gastrointest Liver Physiol 2004; 287: G998-1007.

66 Linden DR, Foley KF, Mcquoid C, Simpson J, Sharkey KA, Mawe GM. Serotonin transporter function and expression are reduced in mice with TNBS-induced colitis. Neurogastroenterol Motil 2005; 17: 565-74.

67 Zarate N, Wang XY, Tougas G et al. Intramuscular interstitial cells of Cajal associated with mast cells survive nitrergic nerves in achalasia. Neurogastroenterol Motil 2006; 18: 556-68.

68 Camilleri M. Management of the irritable bowel syndrome. Gastroenterology 2001; 120: 652-68.

69 Dunlop SP, Jenkins D, Spiller RC. Distinctive clinical, psychological, and histological features of postinfective irritable bowel syndrome. Am I Gastroenterol 2003; 98: 1578-83.

70 Niesler B, Frank B, Kapeller J, Rappold GA. Cloning, physical mapping and expression analysis of the human 5HT3 serotonin receptor-like genes HTR3C, HTR3D and HTR3E. Gene 2003; 310: 101-11.

71 Karnovsky AM, Gotow LF, McKinley DD et al. A cluster of novel serotonin receptor 3-like genes on human chromosome 3. Gene 2003; 319: 137-48.

72 Davies PA, Pistis M, Hanna MC et al. The 5-HT3B subunit is a major determinant of serotonin-receptor function. Nature 1999; 397: 359-63.

73 Brady CA, Stanford IM, Ali I et al. Pharmacological comparison of human homomeric 5-HT3A receptors versus heteromeric 5-HT3A/3B receptors. Neuropharmacology 2001; 41: 282-4.

74 Dubin AE, Erlander MG, Huvar A, Buehler LK. DNA encoding a human subunit 4-HT3-C of the 5-HT3 serotonin receptor. USA patent 20020137138, 2002.

75 Michel K, Zeller F, Langer R et al. Serotonin excites neurons in the human submucous plexus via 5-HT3 receptors. Gastroenterology 2005; 128: 1317-26.

76 Foxx-Orenstein AE, Kuemmerle JF, Grider JR. Distinct 5 -HT receptors mediate the peristaltic reflex induced by mucosal stimuli in human and guinea pig intestine. Gastroenterology 1996; 111: 1281-90.

77 Bjornsson ES, Chey WD, Hooper F, Woods ML, Owyang C, Hasler WL. Impaired gastrocolonic response and peristaltic reflex in slow-transit constipation: role of $5-\mathrm{HT}(3)$ pathways. Am I Physiol Gastrointest Liver Physiol 2002; 283: G400-7.

78 Cremonini F, Delgado-Aros S, Camilleri M. Efficacy of alosetron in irritable bowel syndrome: a meta-analysis of randomized controlled trials. Neurogastroenterol Motil 2003; 15: 79-86.

79 Mader R, Kocher T, Haier J, Wieczorek G, Pfannkuche $\mathrm{HJ}$, Ito $\mathrm{M}$. Investigation of serotonin type 4 receptor expression in human and non-human primate gastrointestinal samples. Eur I Gastroenterol Hepatol 2006; 18: 945-50.

80 Blondel O, Gastineau M, Dahmoune Y, Langlois M, Fischmeister R. Cloning, expression, and pharmacology of four human 5-hydroxytryptamine 4 receptor isoforms produced by alternative splicing in the carboxyl terminus. J Neurochem 1998; 70: 2252-61.

81 Brattelid T, Kvingedal AM, Krobert KA et al. Cloning, pharmacological characterisation and tissue distribution of a novel 5-HT4 receptor splice variant, 5-HT4(i). Naunyn Schmiedebergs Arch Pharmacol 2004; 369: 616-28.

82 Leclere PG, Prins NH, Schuurkes JA, Lefebvre RA. 5-HT4 receptors located on cholinergic nerves in human colon circular muscle. Neurogastroenterol Motil 2005; 17: 36675 . 
83 Cellek S, John AK, Thangiah R et al. 5-HT4 receptor agonists enhance both cholinergic and nitrergic activities in human isolated colon circular muscle. Neurogastroenterol Motil 2006; 18: 853-61.

84 Streutker C, Colley EC, Hillsley K, Hicks GA, Kelly SM, Stead RH. 5-HT4 receptor-immunoreactivity (5-HT4-IR) is expressed in non-neuronal cells of the human gastrointestinal (GI) tract (abstract). Neurogstroenterol Motil 2006; 18: 672 .

85 Schemann M, Michel K, Ceregrzyn M, Zeller F, Seidl S, Bischoff SC. Human mast cell mediator cocktail excites neurons in human and guinea-pig enteric nervous system. Neurogastroenterol Motil 2005; 17: 281-9.

86 Grider JR, Foxx-Orenstein AE, Jin JG. 5-Hydroxytryptamine4 receptor agonists initiate the peristaltic reflex in human, rat, and guinea pig intestine. Gastroenterology 1998; 115: 370-80.
87 Krobert KA, Bach T, Syversveen T, Kvingedal AM, Levy FO. The cloned human 5-HT7 receptor splice variants: a comparative characterization of their pharmacology, function and distribution. Naunyn Schmiedebergs Arch Pharmacol 2001; 363: 620-32.

88 Prins NH, Briejer MR, Van Bergen PJ, Akkermans LM, Schuurkes JA. Evidence for 5-HT7 receptors mediating relaxation of human colonic circular smooth muscle. $\mathrm{Br} J$ Pharmacol 1999; 128: 849-52.

89 Tam FS, Hillier K, Bunce KT. Characterization of the 5-hydroxytryptamine receptor type involved in inhibition of spontaneous activity of human isolated colonic circular muscle. Br J Pharmacol 1994; 113: 143-50.

90 Borman RA, Tilford NS, Harmer DW et al. 5-HT(2B) receptors play a key role in mediating the excitatory effects of 5-HT in human colon in vitro. Br J Pharmacol 2002; 135: 1144-51. 